\title{
The Relationship Between Biomotoric Properties and Hewitt Test Performance in 13-15 Years Old Tennis Players
}

\author{
Ayşegül Yapıc1 ${ }^{1}$ Öznur Akyüz ${ }^{2}$, Müşerref Doruk ${ }^{1}$ \\ ${ }^{1}$ Pamukkale University, Faculty of Sport Sciences, Turkey \\ ${ }^{2}$ Manisa Celal Bayar University, Faculty of Sport Science, Turkey \\ Correspondence: Öznur Akyüz, Manisa Celal Bayar University, Faculty of Sport Science, Turkey.
}

Received: October 12, 2018

doi:10.11114/jets.v6i12a.3685
Accepted: November 26, $2018 \quad$ Online Published: December 4, 2018

URL: https://doi.org/10.11114/jets.v6i12a.3685

\begin{abstract}
Tennis is a sports branch with a lot of coordinated properties. The physical, physiological and motoric properties of the athlete are at optimum level, which influences the stroke performance positively. The aim of this study is to investigate the relationship between biomotoric properties and Hewitt test performance in 13-15 years old tennis players. 10 healthy female tennis players (age: $14.00 \pm 1.05$ years, height: $158.60 \pm 3.69 \mathrm{~cm}$, weight: $53.57 \pm 5.22 \mathrm{~kg}$, experience: $3.40 \pm 1.58$ years) who played in Pamukkale University tennis club participated in this study voluntarily. In anthropometric measurements height, body weight, leg lengths and dominant hand were recorded. Left and right hand grip, countermovement and squat jumps test, flexibility, standing long jump, static and dynamic balance, star test, Wall Catch coordination test and Hewitt performance test were applied to the tennis players. In the statistical analysis of the data, descriptive analyzes of all test performance characteristics of the tennis players were calculated as mean and standard deviation. The relationships between biomotoric properties and Hewitt test performance were evaluated using Pearson Product Moment Correlation analysis. The statistical significance was set at $\mathrm{p}<0.05$. Statistically significant correlation was found between Hewitt test (groundstroke performance) and Wall Catch coordination test $(\mathrm{r}=0.865 ; \mathrm{p}<0.01)$. There was no significant correlation between Hewitt test and leg lengths, dominant hand, left-right foot dynamic balance, standing long jump, flexibility, jump performance, left and right hand grip and star tests ( $>0.05)$. As a result, the use of tests with similar movements special to tennis in evaluating the athlete's performance can accurately reflect the athlete's test values.
\end{abstract}

Keywords: wall catch, performance, balance, strenght

\section{Introduction}

Tennis is a performance sport that requires aerobic and anaerobic loadings to be at a good level in biomotoric properties such as force, speed, endurance, flexibility and coordination (Ferrauti et al, 2002). Age, height, gender, body composition, conditional, biomotor and coordinative characteristics are important factors affecting skill acquisition. Optimal physical, physiological and motoric characteristics of the athlete have a positive effect on performance stroke. There are studies suggesting that coordinating skills and skills are very important for an effective stroke, and that physical fitness parameters such as static and dynamic balance, speed, agility, flexibility with aerobic and anaerobic capacity are important factors in performance (Besier and Lloyd, 2001; Crespo and Miley., 1998; Ferrauti et al., 2002; Kermen, 1997; Ölçücü et al, 2011; Özer and Özer, 2009; Atış et al., 2018). In the studies that has been done, conditional properties that needs to have every tennis player are classified with $15 \%$ strength, $15 \%$ speed, $25 \%$ durability, $35 \%$ coordination and $10 \%$ flexibility (Karagöz, 2008; Akyüz et al., 2017; Doğru et al., 2018).

It is known that the force produced during leg extension and flexion, and transferred from the body to the upper extremity and from there it is transferred to the racket and ball (Schmidt and Wrisberg, 2004). With the onset of movement, the force produced by the lower extremity is transferred to the waist and shoulders, then to the elbow, wrist and racket (Bahamonde, 2000; Elliott et al., 2003; Akyüz et al, 2016). In the tennis game, which is a contactless individual sport, the player needs fast direction changes, quick arm movements, jumps and moves (Gullikson, 2003; Akyüz et al., 2016).

When it comes to thinking that the skills gained at a young age are transferred in the future, it is very important to transfer the skills of the tennis players to the newly acquired skills (Crespo and Miley, 1998, Kermen, 1997, Ölçücü et al., 2011). Children who play sports during the adolescence period exhibit different energy requirements, physical and physiological characteristics which are specific to the branches they are working with. It is tested various physical and motoric 
characteristics which are specific to the general structure of the tennis and then the appropriate training is planned according to these results, in this way the performance of the athlete can be positively effected (Reid et al., 2008). The purpose of this study is to search the relationship between biomaterial properties and ground impact performance in tennis players aged 13-15 years.

\section{Method}

\subsection{Study Group}

10 healthy female tennis players aged 13-15 years (average age: $14.00 \pm 1.05$ years, average length: $158.60 \pm 3.69 \mathrm{~cm}$, average body weight: $53.57 \pm 5.22 \mathrm{~kg}$, playing at Pamukkale University Tennis Club, average training age: $3.40 \pm 1.58$ years) participated voluntarily in this study.

\subsection{Anthropometric Measurements}

height measurements of the subjects were measured with a stadiometer (Seca, Germany) with a sensitivity of $1 \mathrm{~mm}$ and a body weight of $0.1 \mathrm{~kg}$. The measurements were made at the anatomical posture by keeping heels together, by holding the breath, by fitting the head in frontal stage, after the position of the head-top touching the vertex point had been taken, the measurement was recorded as $\mathrm{cm}$, and $\mathrm{kg}$. The leg lengths of the tennis players were measured by measuring the distance between anterior superior iliac spine and tibial medial malleousu.

\subsection{Hand Gripping Force Measurement}

Takei Physical Fitness Test (Japan) hand dynamometer which can measure the force between $0 \mathrm{~kg}$ and100 $\mathrm{kg}$ is used on the right and left hand gripping forces of the subjects. The hand grip strength measurement of the subjects was made while they were standing. After the dynamometer had been adjusted according to the hand size of the subjects, the arms of the subjects were measured at the side while the arms were making an angle of 10-15 degrees from the shoulder. The best values were recorded as right and left hand gripping forces after two attempts for both hands (Zorba, 2000; Tamer, 2000).

\subsection{Flexibility Measurement}

The flexibility of the participating tennis players was measured and the seat-access platform was used. The subjects were given two chances as in the naked feet and the best result was recorded in $\mathrm{cm}$ (Zorba, 2000).

\subsection{Vertical Jumping Measurement}

In the vertical jump test, the iPhone My Jump 2 program was used (Fernandez et al., 2015). In the active jump, the subjects tried to reach the highest point where they could leap without bending their knees. In Squat's jump, the subjects tried to reach the highest point where the hands were at the full squat position with their hands on the waist and they could leap from the knees with maximum force without any movement of spring. Measurements were taken as $\mathrm{cm}$. After each measurement, the device was reset and attention was paid to the stability of the device. 2 measurements were made and the best ratings were recorded.

\subsection{Long Jump Measurement by Stopping}

In the standing position without taking speed, the double leg is measured in $\mathrm{cm}$ between the line at the point of jump and the distance left by the last mark at the long jump which made in connection with each other. The participants were given the test twice again and the best result was recorded (Sevim, 1997).

\subsection{Balance Measurement}

Static balance measurement; flamingo balance test was applied. In the test, a wooden balance tool that is $50 \mathrm{~m}$ length, 4 $\mathrm{cm}$ height and $3 \mathrm{~cm}$ width was used. When the subjects were in equilibrium with one foot, the time was started and tried to stabilize for 1 minute. If the subject lays his foot while holding the foot, falls from the wooden floor, he touches the floor with any part of his body and so on, the time has been stopped. When the balance was restored by riding up balance device, the time was restarted. When the period was completed, each balance supply attempt was counted, this number was recorded as points at the end of the test (Bressel et al, 2007).

In dynamic balance measurement; SEBT (Star Excursion Balance Test) battery was applied. In the measurement, the distance among the three graveyards is 120 degrees. Before starting the test, the athlete made dynamic warming and stretching for 10 minutes. The subject stood shoe-free on the central junction. While the test was in the starting position as a foot balance knee, above the center junction, the leg stayed slightly behind the knee. In the test protocol, the order is as follows: anterior, posteromedial, posterolateral. Subjects were given two trials before the actual measurement. In the measurements, three measurements were taken for each direction on both legs. Two minutes resting time between the experiments were given. During the test, it is desirable that the leg extending from the subjects is touched very lightly with their toe tips and returned to the starting position. Measurements are repeated if the athlete's hands leave his waist, if the athlete is out of balance, if the heel is lifted, if the balance loses its position in the starting position, if the extending leg has 
assisted the balance leg and has touched the floor to support balance, if the leg has been used with the aim of extending the leg to support base and balance area (Olmsted et al., 2002). Dynamic equilibrium scores; To calculate the reach distance, the average of the three measurements taken in each direction was divided into the leg length and multiplied by 100. In addition, to obtain a combined dynamic balance score with the SEBT battery, averages of the calculated values of distances in 3 directions were taken.

\subsection{Star Test Measurement}

It was placed 3 tennis balls at equal intervals to the mini-court line. The athlete, starting from the bottom line, placed the balls one by one on the bottom line racket. When the 3 balls were collected on the racket, the test was completed and recorded as the best degree seconds in 2 repeats (Karagöz et al., 2015).

\subsection{Wall Catch Coordination Test Measurement}

The subject stays by facing the wall at a distance of 3 meters. The ball is thrown from the bottom to the top on the condition that catching the ball with the same hand that the ball is thrown. After a certain number of tests, the other hand is tested. Scoring of successful shoots is done in the same way in both hands. In order to assist in the evaluation of the results, the shots of the subject's preferred hand were recorded (Burn, 1979).

\subsection{Hewitt Test Measurement}

The opposite side of the court was scored by dividing by 4 . The tennis net and the first intervals are scored (4.5 meters),as 2 points, the second and third intervals are scored (4,5 meters) as 3 points, the third and fourth intervals ( 4,5 meters) are scored as 4 points. A total of 12 balls were thrown to the athletes by a racquet from the mini court line of the opposing field of the subjects and the athletes are scored points according to the first fall range of the ball by shooting forehand and backhand respectively. In the event of an incorrect stroke, if the ball falls out of the field lines and if the ball is inserted into the netting, if the ball is bounced twice in the ground, a score of zero is given (Hewitt, 1966).

\subsection{Analysis of Data}

In the statistical analysis of the data, descriptive statistical values related to all test performance characteristics of the tennis players were calculated as mean and standard deviation. The relationship between biomotor features and ground impact performance in tennis players was examined by Pearson Correlation analysis.

\section{Results}

The physical characteristics of the participating tennis players and the performance values obtained from the tests are shown in Table 1.

Table 1. Descriptive Statistical Table of Physical and Biomorphological Characteristics of Tennis Players Attending to Study

\begin{tabular}{ll}
\hline Physical and Biomorphic Properties & $\mathrm{X} \pm \mathrm{SS}$ \\
\hline Age (years) & $14,00 \pm 1,05$ \\
Length (cm) & $158,60 \pm 3,69$ \\
Body Weight (kg) & $53,57 \pm 5,22$ \\
Training Age (years) & $3,40 \pm 1,58$ \\
Leg Length (cm) & $82,70 \pm 3,33$ \\
Right Foot Dynamic Balance (cm) & $91,01 \pm 9,25$ \\
Left Foot Dynamic Balance (cm) & $91,39 \pm 8,55$ \\
Standing Long Jump (cm) & $150,20 \pm 16,34$ \\
Flexibility (cm) & $24,12 \pm 4,73$ \\
Active Jump (cm) & $23,90 \pm 2,31$ \\
Squat Jump (cm) & $21,62 \pm 2,65$ \\
Right Hand Gripping Force & $24,29 \pm 2,98$ \\
Left Hand Gripping Force (kg) & $20,59 \pm 4,32$ \\
Star Test (sec & $13,98 \pm 0,83$ \\
Wall Catch Coordination Test & $9,20 \pm 1,93$ \\
Hewitt Test & $18,20 \pm 4,83$ \\
\hline
\end{tabular}

The relationship between the Hewitt test (ground impact performance) and biomotor characteristics of the participating tennis players is given in Table 2 .

Table 2. The Relationship Table Between Biomotoric Properties and Bounce Performance

\begin{tabular}{llllllllllll}
\hline & & SADD & SOADD & DUA & Esneklik & AS & SS & SEK & SEK & YT & WCKT \\
\hline \multirow{2}{*}{ Hewitt Testi } & r & $-0,002$ & $-0,188$ & 0,195 & 0,503 & 0,355 & 0,267 & 0,098 & 0,547 & $-0,445$ & $0.865^{* *}$ \\
& p & 0,996 & 0,603 & 0,59 & 0,138 & 0,314 & 0,456 & 0,788 & 0,102 & 0,198 & 0,001 \\
\hline
\end{tabular}

** $\mathrm{p}<0.01$; SADD: Right Foot Dynamic Balance; SOADD: Dynamic Equilibrium; DUA: Long Jump; AS: Active Bounce; SS: Squat Bounce; SEK: Right Hand Grip; SOEK: Left Hand Grip; PT: Star Test; WCKT: Wall Catch Coordination Test). 
In this study, a statistically significant relationship was found between the Hewitt test (ground stroke performance) and Wall-Catch coordination test $(r=0.865 ; \mathrm{p}<0.01)$. There was no statistically significant relationship between leg length, dominant hand, right-left foot dynamic balance, standing long jump, flexibility, active-squat jump, right-left hand grip strength and star test on ground stroke performance test ( $p>0.05)$.

\section{Discussion and Conclusion}

As an individual sport, tennis is a sport in which the level of physical fitness such as quick changes in direction of movement, quick and strong arm movements and jumps that are at the top level. Achieving successes due to these features is possible by doing the sport from the earliest ages and by practicing training programs as much as possible and that will improve the biomotorics of children such as coordination, agility, strength, speed, flexibility and balance (Chu, 1995; Akyüz et al., 2016).

In the tennis players, the lower extremity strength provides the fastest way to reach the ball during the match, while the upper extremity strength also makes the ball faster. A proper racket grip helps to protect the arm balance, especially during off-center beats, while preventing injuries on the wrist and elbow. In this sense, it is considered that hand anthropometric measurements and grip strength values are important in directing the athlete in sports branches where hand use is important. Arslan (2009) found that the dominant hand strengths of the tennis players were $55.57 \pm 3.36 \mathrm{~kg}$ and the non-dominant hand grip strengths were $47.49 \pm 3.19 \mathrm{~kg}$. In another study; from, Gelen et al (2006), dominant hand grip strength values of tennis players in 1st league were $46.2 \pm 3,43 \mathrm{~kg}$, and non-dominant hand grip strength was $39,6 \pm$ $3,41 \mathrm{~kg}$. 2. The dominant hand grip strength values of the league tennis players are; $46.0 \pm 4.90 \mathrm{~kg}$, non-dominant hand grip strength values are $37.7 \pm 4.96 \mathrm{~kg}$. In this study it is seen that hand grip strength of the subjects participating in the research is low. Due to the fact that the hand strength is inadequate, the elastic force transmitted from the arm to the racket during the stroke is reduced, it is seen that the accuracy rate of the stroke is reduced.

In the tennis players whose agility and flexibility are not good enough, these problems are encountered such as high risk of injury, lack of quality of movement and slowing of the overall performance development, and the prevention of the development of force and velocity characteristics (Schönborn, 2000). Acceleration and short sprints in a tennis court are important to an athlete who wants to achieve a balanced shot. Equilibrium plays a pivotal role in many of the skills such as serving, hitting the ball, bouncing the ball or meeting the ball (Evangelos, 2012). Successful and effective performance of any technical skill relates to the ability of tennis players to control their balance and to show a good and rapid adaptation to their position on the changing body posture and court during training or competition. In this study; In the tennis players at the age of 13 to 15 years, there is not found statistically significant difference between the ground stroke performance, leg length, dominant hand, right-left foot dynamic balance, standing long jump, flexibility, active-squat jump, right-left hand grip strength and stellar test ( $>0.05$ ). The Hewitt test is a performance test that measures the motion of strokes on the ground. It is expected that there will be a negative relation between the ground stroke movements and the values of star test, speed test and equilibrium test in tennis sport. Because of the star test that measures the agility skill in tennis sport, the speed tests that measure the skill of speed are expected to make a better timing and hitting the ball quickly. In addition, the high static balance performance of the athlete will have a positive impact on ground impact performance. It is expected that long jump, flexibility, ball launch and dynamic equilibrium will be positively correlated with similar reasons (Hudson, 2007; Roetert et al., 1996).

The most important part of the tennis branch in terms of training parameters is the coordination training. Hudson (2007), in his study, emphasized that coordination training is especially important for motor development in young children. The learning curves exhibit high individual differences in skills that require coordination. He explained that some athletes learned faster than others. When these results are examined, it is concluded that the trainings made a positive contribution to the ability of the ball to hit the ball. Schmidt and Wrisberg (2004) show that in their study of the factors affecting motor learning in tennis, while they apply tennis techniques, the chain of action is very important and in addition, the principles of kinetic chain will help to make the movements more smooth and effective without the risk of disability. Dyer (1998), designed the wall test from the strokes against the wall in order to rate the skill level of the tennis players. 736 female college players were included in the study and the correlation scores of the test scores and the league-style tournament results were evaluated. In the study, the correlation coefficient between 0.85 and 0.92 was determined.

In another study, after 8-week (16 lessons, 1 hour) training on 8 mid-level men over the age of 20, Revised Dyer wall test was applied to determine the players' learning levels. After the tests, a strong correlation value was determined as 0,84-0,90 between the achievement levels and test scores of the players. In the studies, a very strong relationship between Revised Dyer wall test and Hewitt test was found as 0,92-0,99 (Stoebe, 1976). In this study, a statistically significant relationship was found between the Hewitt test (ground stroke performance) and Wall-Catch coordination test $(\mathrm{r}=0.865$; $\mathrm{p}$ <0.01). Çimen and Günay (1996), in their study, investigated the effect of rapid force on motoric properties and the reason of the technical characteristics observed in athletes was the result of the positive contribution of coordination 
trainings along with strength training to the neuromuscular coordination. In this study, it was concluded that the existing coordinative features have a positive effect on the forehand technique after Wall Catch coordination test.

As a result; the use of tests with similar movements specific to tennis in assessing the performance of athletes may accurately reflect the athlete's test values. The lack of training and the level of professionalism and insufficient number of subjects may limit this study results.

\section{References}

Akyüz, M., Agar, M., Akyüz, Ö., \& Dogru, Y. (2016). Motivational Factors Affecting Athletes in Selecting the Sport Branches of Athletics, Ski and Tennis. Journal of Education and Training Studies, 4(12), 160-165. https://doi.org/10.11114/jets.v4i12.1961

Akyüz, M., Özmaden, M., Doğru, Y., Karademir, E., Aydın, Y., \& Hayta, Ü. (2017). Effect of static and dynamic stretching exercises on some physical parameters in young basketball players. Journal of Human Sciences, 14(2), 1492-1500. https://doi.org/10.14687/jhs.v14i2.4560

Akyüz, M., Uzaldi, B. B., Akyüz, Ö., \& Doğru, Y. (2016). Comparison of Sprint Reaction and Visual Reaction Times of Athletes in Different Branches. Journal of Education and Training Studies, 5(1), 94-100. https://doi.org/10.11114/jets.v5i1.1987

Akyüz, Ö., Çoban, C., Dilber, A. O., Ergün, Z., Murat, T., Özkan, I, Doğru, Y., \& Akyüz, M. (2016). İşitme Engellilerde Statik Denge Düzeylerinin Belirlenmesi. Gaziantep Üniversitesi Spor Bilimleri Dergisi, 1(2), 110-116.

Arslan, Y. (2009). Elit Badminton ve tenis oyuncularının bazı antropometrik özellikleri ve oransal ilişkilerinin karşılaştırılması. Yüksek lisans tezi, Gazi Üniversitesi, Ankara.

Atış, E., Gelen, E., \& Yıldız, S. (2018). The acute effect of different frequencies of whole-body vibration on range of motion and jump performance in preadolescent karate athletes. Turkish Journal of Sport and Exercise, 20(2), 122-126. https://doi.org/10.15314/tsed.418996

Bahamonde, R. E. (2000). Changes in angular momentum during the tennis serve. Journal of Sports Science, 18(8), 579-592. https://doi.org/10.1080/02640410050082297

Besier, T. F., \& Lloyd, T. R. (2001). Ackland and jl cochrane. anticipatory effects on knee joint loading during runnin gand. cutting maneuvers. Medicine and Science in Sports \& Exercise, 33(7), 1176-1181. https://doi.org/10.1097/00005768-200107000-00015

Bressel, E., Yonker, J. C., Kras, J., \& Heath, E. M. (2007). Comparison of static and dynamic balance in female collegiate soccer, basketball, and gymnastics athletes. Journal of Athletic Training, 42(1), 42.

Burn, B. (1979). The Science of Table Tennis. London: Pelham Books.

Chu, D. A. (1995). Power tenis training. Champaign, IL: Human Kinetics.

Çimen, O., \& Günay, M. (1996). Dairesel çabuk kuvvet antrenmanlarının 16-18 yaş grubu erkek masa tenisçilerinin bazı motorik özelliklere etkisi. Gazi Üniversitesi Spor Bilimleri Dergisi, 8(3), 3-11.

Crespo, M., \& Miley, D. (1998). Advanced coaches manual, West Bay Street Nassau, . Bahamas Canada.

Doğru, Y., Akyüz, M., Akyüz, Ö., Murat, T., Çoban, C., \& Dilber, A. O. (2018). The Effect of Eight-Week Resistance Exercise Program on Static Balance in Sedentary Men Aged 20-40 Years. International Journal of Science Culture and Sport, 6(2), 245-253. https://doi.org/10.14486/IntJSCS756

Dyer, J. T. (1998). Revision of the backboard test of tennis ability. Research Quarterly, 9(1), 25-31.

Elliott, B., Fleisig, G., Nicholls, R., \& Escamilia, R. (2003). Technique effects on upper limb loading in the tennis serve. Journal of Science and Medicine Sport, 6(1), 76-87. https://doi.org/10.1016/S1440-2440(03)80011-7

Evangelos, A. (2012). Proprioception and balance training can improve amateur soccer players' technical skills. Journal of Physical Education and Sport, 12(1), 81-89.

Fernandez, B. C., Glaister, M., \& Lockey, A. R. (2015). The validity and reliability of an iPhone app for measuring vertical jump performance. Journal of Sports Science, 33(15), 1574-1579. https://doi.org/10.1080/02640414.2014.996184

Ferrauti, A., Maier, P., \& Weber, K. (2002), Tennistraining. Meyer und Meyer Verlag, Deutchland

Gelen, E., Saygın, Ö., Karahan, M., \& Karacabey, K. (2006). 1. ve 2. ligdeki tenisçilerin fiziksel uygunluk özelliklerinin karşılaştırılması. Fırat Üniversitesi Sağlık Bilimleri Tip Dergisi, 20(2), 119-127.

Gullikson, T. (2003). Teniste Fiziksel Uygunluk Testleri. (Çev. Yavuz Yarsuvat) Spor Araştırmaları Dergisi. 7(1), 
$135-156$.

Hewitt, J. E. (1966). Hewitt's tennis achievement test. Research Quarterly, 37, 231-210. https://doi.org/10.1080/10671188.1966.10613366

Hudson, J. K. (2007). Biomechanic of balance: paradlgms and procedures. California State University, Chicago, USA.

Karagöz, G. (2008). 8-10 yaş arası çocuklarda 12 haftalık tenis antrenmanlarının görsel ve işitsel reaksiyon zamanına etkisinin incelenmesi. Yüksek lisans tezi, Afyon Kocatepe Üniversitesi, Afyon.

Karagöz, Ş., Erdoğmuş, M., Celepaksoy, F., Bozlak, K., \& Alkan, F. (2015). Minik tenisçilerde bazı fiziksel ve fizyolojik parametrelerin yer vuruş performansına etkisinin incelenmesi, Niğde Üniversitesi Beden Eğitimi ve Spor Bilimleri Dergisi, Cilt 9, Özel sayı.

Kermen, O. (1997). Tenis teknik ve taktikleri. İstanbul Aşama Matbaacılık.

Ölçücü, B., Canikli, A., Hadi, G., \& Taşmektepliğil, M. Y. (2011). 12-14 yaş kategorilerindeki bayan tenis oyuncularının fiziksel ve fizyolojik özellikleri. Spor ve Performans Araştırmaları Dergisi, 3(1), 5-24.

Olmsted, L. C., Carcia, C. R., Hertel, J., \& Shultz, S. J. (2002). Efficacy of the star excursion balance tests in detecting reach deficits in subjects with chronic ankle stabilanity. Journal of Athletic Training, 37(4), 501-506.

Özer, S. D., \& Özer, K. (2009). Çocuklarda motor gelişim. Nobel yayın evi, 6.Baskı. Ankara.

Reid, M., Elliott, B., \& Alderson, J. (2008). Lower-limb coordination and shoulder joint mechanics in the tennis serve. Medicine Science and Sports Exercise, 40, 308-315. https://doi.org/10.1249/mss.0b013e31815c6d61

Roetert, E. P., Kibler, W. B., Chandler, T. J., \& Livingston, B. P. (1996). Shoulder range of motion in elite tennis players, effect of age and years of tournament play. American Journal of Sports Medicine, 24(3), 279-285. https://doi.org/10.1177/036354659602400306

Schimdt, R. A., \& Wrisberg, C. A. (2004). Motor learning and performance. USA.

Schönborn, R. (2000). Advanced techniques for competttve tennis, meyer\&meyer sport, Germany, 83-118.

Sevim, Y (1997). Antrenman Bilgisi. Ankara: Tutibay Ltd. Şti.

Stoebe, H. E. (1976). The relationship of grip strength and tennis ability. Master's thesis, School of health physical education and recreation, University of Wisconsin-La Crosse.

Tamer, K. (2000). Sporda Fiziksel ve Fizyolojik Performansın Ölçülmesi ve Değerlendirilmesi. Ankara: Bağırgan Yayınevi.

Zorba, E. (2000). Fiziksel Uygunluk. Ankara: Neyir Matbaası.

\section{Copyrights}

Copyright for this article is retained by the author(s), with first publication rights granted to the journal.

This is an open-access article distributed under the terms and conditions of the Creative Commons Attribution license which permits unrestricted use, distribution, and reproduction in any medium, provided the original work is properly cited. 